\title{
PENENTUAN PRIORITAS PENINGKATAN PELAYANAN PENERANGAN JALAN DI KOTA KEDIRI
}

\section{PRIORITY DETERMINATION OF STREET LIGHTING SERVICES IMPROVEMENT IN KEDIRI CITY}

\author{
Jimmy Septian Christiawana, Yudi Basuki ${ }^{\text {B }}$ \\ aDinas Perumahan dan Kawasan Pemukiman Kota Kediri; Jalan Brigjen Pol. Imam Bachri 100 B Kota Kediri; jimsalc98@gmail.com \\ bDepartemen Perencanaan Wilayah dan Kota; Universitas Diponegoro, Semarang, Jawa Tengah; yudibasuki@yahoo.com
}

Info Artikel:

- ArtikelMasuk: 15 November 2018

\begin{abstract}
ABSTRAK
Kota Kediri memiliki peran sebagai Satuan Wilayah Pengembangan bagi wilayah di sekitarnya. Peran tersebut berfokus pada sektor perdagangan barang dan jasa, industri, dan pendidikan. Dampaknya adalah terjadinya peningkatan aktivitas kota, termasuk pada sektor transportasi. Keberadan lampu jalan sebagai bagian dari sarana pelengkap jalan memiliki fungsi yang penting dalam menunjang keselamatan pengguna jalan dan peningkatan ekonomi kota. Namun, pelayanan penerangan jalan di Kota kediri belum memenuhi standar minimal yang disyaratkan. Sehingga peningkatan layanan penerangan jalan mutlak diperlukan. Keterbatasan sumber daya yang tersedia menyulitkan Pemerintah Kota Kediri dalam meningkatkan layanan penerangan jalan secara keseluruhan. Berdasarkan permasalahan tersebut, penelitian ini bertujuan menentukan prioritas peningkatan pelayanan penerangan jalan di Kota Kediri. Metode yang digunakan adalah metode gabungan, yaitu kualitatif dan kuantitatif dengan menggunakan Analysis Hierarchy Process (AHP) dan weighted overlay. AHP digunakan untuk menentukan bobot setiap variabel terhadap penentuan prioritas. Analisis weighted overlay digunakan untuk menentukan prioritas peningkatan lampu jalan dengan memadukan bobot variabel hasil AHP dan nilai variabel pada setiap ruas jalan. AHP menghasilkan bobot tertinggi dalam perencanaan peningkatan penerangan jalan adalah tingkat kerawanan kecelakaan (16\%) dan jumlah persimpangan (12,49\%).Analisis akhir menghasilkan empat tingkat prioritas. Prioritas utama terdapat pada ruas jalan Kapten Tendean dan K.H. Ahmad Dahlan.
\end{abstract}

Kata Kunci : penerangan jalan, analytical hierarchy process, weighted overlay

\section{ABSTRACT}

Kediri city has a role as a Regional Development Centre for the region around it. The role focuses on the trade in goods and services, industry and education. The impact is an increase in urban activity, including in the transportation sector. The existence of street lights as part of road complementary facilities has an important function in supporting road user safety and improving the city's economy. However, street lighting services in Kediri City do not meet the minimum standards required. So that an increase in street lighting services is absolutely necessary. The limited available resources make it difficult for the Kediri City Government to improve overall street lighting services. Based on these problems, this study aims to determine the priority of improving street lighting services in Kediri City. This research use mix method, namely use the qualitative and quantitative approachment, using the Analytical Hierarchy Process (AHP) and weighted overlay as analytical tools. AHP is used to determine the weight of each variable for priority setting. Weighted overlay analysis is used to determine the priority of road lights improvement by combining the weight variables of AHP results and variable values on each road segment. The AHP produced the highest weight in planning for increasing street lighting was the accident hazard rate (16\%) and the number of intersections (12.49\%). The final analysis produces four priority levels. The main priorities are on the Kapten Tendean and K.H.Ahmad Dahlan road sections

Keyword: street lighting, analytical hierarchy process, weighted overlay 
Christiawan, Basuki / Jurnal Pembangunan Wilayah dan Kota, Vol 15, No1, 2019, 33-46 Doi: 10.14710/pwk.v15i1.21066

\section{PENDAHULUAN}

Peran Kota Kediri di wilayah Jawa Timur adalah sebagai salah satu pusat pelayanan dan jalur transportasi regional. Peranan tersebut menuntut Kota Kediri untuk siap dalam menghadapi perkembangan dan aktivitas perkotaan, termasuk pada sistem transportasi. Peningkatan volume lalu lintas akibat peningkatan aktivitas kota telah dapat dirasakan dengan adanya beberapa titik pusat kemacetan di Kota Kediri. Respon pemerintah terhadap hal ini, salah satunya adalah dengan melakukan pengaturan lalu lintas, peningkatan kualitas dan kapasitas jalan, serta pembangunan jembatan. Namun respon tersebut belum diimbangi dengan peningkatan kualitas penerangan jalannya. Kondisi tersebut belum dengan peraturan Badan Standarisasi Nasional (2008) dalam SNI 7391: 2008, yang menyatakan bahwa setiap jalan harus dilengkapi dengan penerangan jalan umum (LPJU) yang memenuhi persyaratan. Penerangan jalan merupakan bangunan pelengkap jalan yang penting karena memiliki fungsi utama untuk meningkatkan keselamatan pengguna jalan. Penerangan jalan memiliki fungsi tambahan untuk meningkatkan omset penjualan pada daerah komersil (Jin et al, 2017). Pada area industri, penerangan jalan sangat berperan pada distribusi barang di malam hari. Tujuan pembangunan berkelanjutan bergantung pada desain dan operasi infrastruktur perkotaannya, tetapi dalam penyediaan fasilitas LPJU, hal tersebut sering dilupakan (Garrido-Jiménez et al, 2017). Penerangan jalan di Kota Kediri sebagian besar belum memenuhi standar teknis. Hal tersebut berdampak pada tingkat keselamatan pengguna jalan. Pada tahun 2016 terjadi 44 kasus kecelakaan dan meningkat menjadi 438 kasus kecelakaan pada tahun 2017 (Kepolisian Resor Kota Kediri, 2017), yang salah satu penyebabnya adalah kurangnya penerangan jalan. Saraiji et al (2009) menjelaskan bahwa $85 \%$ persimpangan jalan raya dengan tingkat kecelakaan tinggi, tidak memiliki penerangan yang layak.

Masalah umum layanan penerangan jalan adalah pada sektor teknis, salah satunya adalah jarak antara lampu jalan (Murray \& Feng, 2016). Berdasarkan pada SNI 7391: 2008, lebar jalan memiliki pengaruh pada jarak dan ketinggian tiang lampu yang dikaitkan dengan pemerataan pencahayaan Peningkatan kualitas dan kapasitas jalan di Kota Kediri seringkali tidak diikuti oleh peningkatan desain LPJU (jarak antar lampu, ketinggian, serta pemerataan pencahayaan). Sebagian besar penempatan lampu PJU di Kota Kediri tidak sesuai dengan standar. Ini karena LPJU dipasang pada tiang listrik PLN, yang memiliki jarak antara 50 meter. Permasalahan lain adalah perubahan fungsi lahan yang tidak diikuti oleh peningkatan kualitas LPJU nya. Fungsi yang berbeda memerlukan tingkat pelayanan yang berbeda pula, sebagai contoh peran LPJU di area komersial tidak hanya untuk meningkatkan keselamatan pengguna jalan, tetapi juga berperan dalam meningkatkan omset penjualan (Jin et al, 2017). Beberapa faktor lain adalah perubahan kelas jalan, jumlah persimpangan, peningkatakan volume lalu lintas, dll. Faktor- faktor tersebut membutuhkan tingkat layanan lampu jalan yang berbeda (Feng \& Murray, 2017). Volume lalu lintas memiliki korelasi dengan tingkat keselamatan pengguna jalan (Antoro, 2006). Volume lalu lintas yang lebih tinggi akan meningkatkan resiko angka kecelakaan. Al Irsyad \& Nepal (2016) juga berpendapat bahwa salah satu aspek yang dipertimbangkan dalam upaya meningkatkan kualitas lampu jalan adalah intensitas lalu lintas.

Peningkatan kualitas layanan penerangan jalan mutlak diperlukan untuk mengakomodasi perkembangan Kota Kediri. Namun, upaya ini tidak dapat dilaksanakan dengan lancar karena keterbatasan dana dan daya listrik untuk meningkatkan layanan LPJU. Alokasi dana diprioritaskan pada pembangunan jaringan LPJU baru dan biaya operasional, sementara peningkatan layanan LPJU eksisting sering diabaikan (Mirzaei et al, 2015). Keterbatasan daya dan biaya yang disebabkan tidak efisiennya pengeloaan bidang penerangan jalan, berdampak pada meningkatnya beban pembiayaan penerangan jalan (al Irsyad \& Nepal, 2016). Pada beberapa lokasi di Kota Kediri terdapat jaringan LPJU yang tidak memiliki meter daya, jaringan LPJU ilegal, penggunaan pemutus sirkuit miniatur (MCB) yang melebihi standar PLN, serta penggunaan lampu dengan daya yang relatif tinggi (250-400 watt). Selain tidak hemat listrik, penggunaan lampu dengan daya tinggi menyebabkan tagihan rekening LPJU tinggi, juga menyebabkan emisi CO2 yang sangat besar (Carli, Dotoli, \& Cianci, 2017). Oleh karenanya penelitian ini bertujuan untuk menentukan prioritas peningkatan layanan penerangan jalan di Kota Kediri. Penentuan prioritas dilaksanakan menggunakan 
variabel-variabel 1) yang digunakan pada penelitian terdahulu dalam melakukan evaluasi penerangan jalan; 2) standar perencanaan penerangan jalan; serta 3) kajian empiris stakeholder di Kota Kediri. Variabel terbentuk meliputi: gambaran jalan, teknis penerangan jalan, kondisi lalu lintas, efisiensi daya dan biaya, serta pengembangan wilayah.

Pembobotan kriteria dan sub kriteria, serta identifikasi kondisi eksisting setiap ruas jalan diperlukan dalam menentukan prioritas. Pembobotan dilakukan untuk mengetahui tingkat kepentingan setiap kriteria dan sub kriteria, sedangkan identifikasi nilai sub kriteria diperlukan untuk mengetahui kondisi eksiting setiap ruas jalan. Penentuan prioritas dilakukan dengan memadukan pengaruh sub kriteria dengan nilai sub kriteria per ruas jalan. Penelitian ini secara praktis dapat membantu pemangku kebijakan dalam menentukan prioritas peningkatan layanan penerangan jalan. Secara teoritis akan memberikan ide perencanaan yang lebih komprehensif dengan memadukan kondisi di lapangan serta pembobotan dari para stakeholder.

\section{DATA DAN METODE}

\subsection{Metode Penelitian}

Penelitian ini menggunakan metode gabungan, yaitu suatu langkah penelitian dengan menggabungkan dua pendekatan dalam penelitian, yaitu kuantitatif dan kualitatif (Creswell, 2015). Analisis data dilakukan dengan teknik campuran bertahap, yaitu dengan cara memberikan bobot pada data kuantitatif. Strategi yang digunakan adalah strategi eksporatoris sekuensial, yaitu mengumpulkan dan menganalisa data kualitatif, kemudian mengumpulkan data kuantitatif dan menganalisanya pada tahap kedua yang didasarkan pada hasil tahap pertama. Bobot utama pada strategi ini adalah pada data kualitatif. Tahap pertama adalah melakukan pengumpulan data. Kriteria dan sub kriteria terbentuk digunakan sebagai dasar untuk mendapatkan data kualitatif maupun kuantitatif. Data kualitatif didapatkan dengan melakukan interview kepada para ahli. Data kualitatitf berupa perbandingan kepentingan masingmasing kriteria dan sub kriteria. Data kuantitatif didapatkan dengan survei primer dan sekunder berdasarkan kriteria dan sub kriteria terbentuk. Data kuantitatif berupa nilai masing-masing sub kriteria per ruas jalan. Kriteria dan sub kriteria dimaksud didapatkan melalui studi literatur dan kajian empiris di lapangan. Tahap kedua adalah menentukan bobot variabel dalam menentukan prioritas peningkatan layanan penerangan jalan. Analisis penentuan bobot variabel menggunakan metode analytical hierarchy process (AHP). Proses AHP dilakukan dengan menyusun tujuan, kriteria, dan sub kriteria ke dalam model hirarki sampai dengan level 3, dimana level 1 adalah tujuan. Level 2 adalah kriteria , dan level 3 adalah sub kriteria.

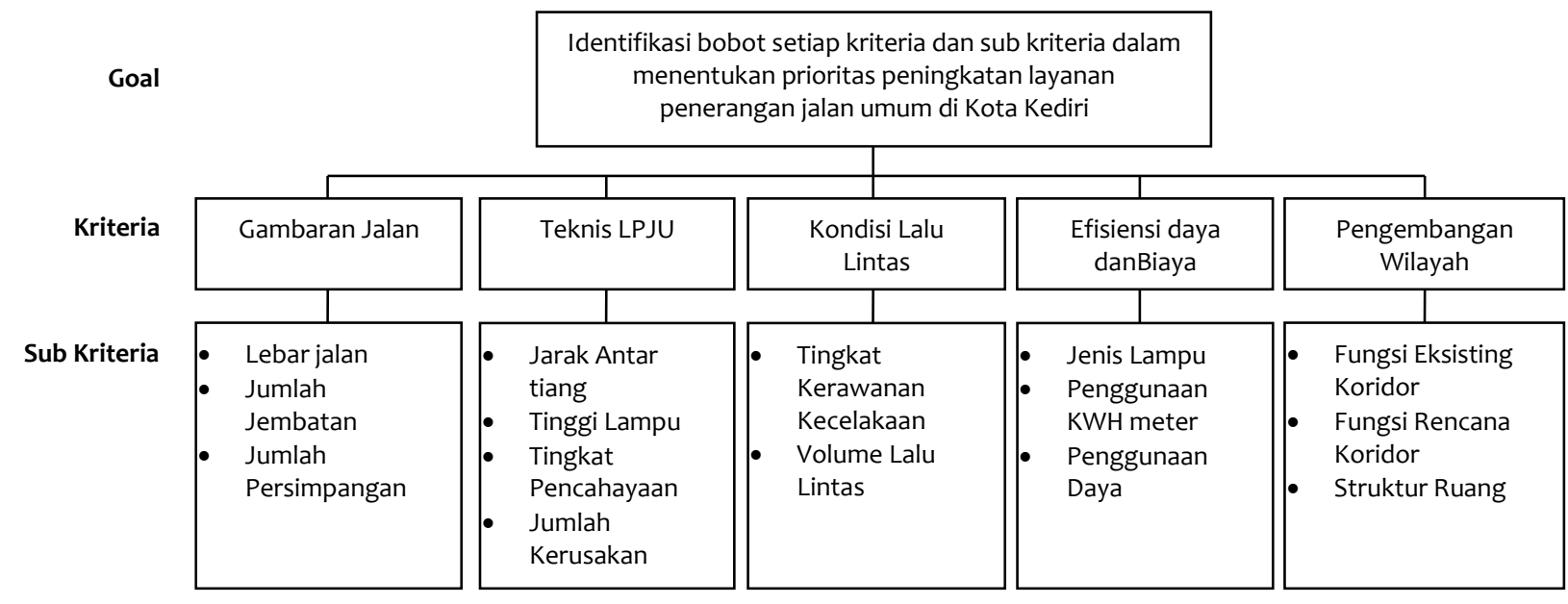

Gambar 1. Struktur Hirarki AHP (hasil analisis, 2018) 
Proses selanjutnya adalah pembobotan tingkat kepentingan masing-masing kriteria dan sub kriteria. Langkah pertama adalah membuat matrik berpasangan, yang digunakan untuk memberikan nilai perbandingan kepentingan antar kriteria dan sub kriteria. Pengisian matrik berpasangan menggunakan skala perbandingan 1-9 seperti terlihat dalam tabel 1. Pada penelitian ini responden berjumlah 6 orang yang merupakan stakeholder/pakar terkait bidang transportasi, khususnya sektor penerangan jalan. Responden berasal dari Badan Perencanaan Penelitian dan Pembangunan Kota Kediri, Dinas Pekerjaan Umum dan Penataan Ruang Kota Kediri, Dinas Perumahan dan Kawasan Pemukiman Kota Kediri, Polres Kota Kediri, Dinas Perhubungan Kota Kediri, serta akademisi dari Universitas Kediri.

Tabel 1. Skala ranking Saaty (Khaki, 2015)

\begin{tabular}{|c|l|}
\hline Tingkat Kepentingan & \multicolumn{1}{|c|}{ Definisi } \\
\hline $\mathbf{1}$ & Sama Penting \\
\hline $\mathbf{3}$ & Sedikit lebih penting \\
\hline $\mathbf{5}$ & Jelas lebih penting \\
\hline $\mathbf{7}$ & Sangat jelas lebih penting \\
\hline $\mathbf{9}$ & Pasti/mutlak lebih penting (kepentingan yang ekstrim \\
\hline $\mathbf{2 , 4 , 6 , 8}$ & Jika ragu-ragu antara dua nila yang berdekatan \\
\hline $\mathbf{1 ( 1 - 9 )}$ & Kebalikan nilai tingkat kepentingan dari skala 1-9 \\
\hline
\end{tabular}

Langkah kedua adalah menguji konsistensi nilai pada matrik berpasangan, dimana rasio konsistensi yang wajar digunakan tidak boleh lebih dari $10 \%$. Apabila lebih dari $10 \%$, maka perlu dilakukan pengulangan pengisian kuisioner matrik berpasangan. Langkah ketiga adalah menyatukan nilai matrik berpasangan semua responden, dan melakukan pembobotan yang menghasilkan prosentase tingkat kepentingan masing-masing kriteria dan sub kriteria. Tahap ketiga adalah penentuan prioritas peningkatan layanan penerangan jalan per ruas jalan, menggunakan analisis weighted overlay. Analisis ini menggabungkan data kuantitatif berupa nilai pada masing-masing variabel terbentuk dan data kualitatif berupa bobot masingmasing variabel. Proses analisis weighted overlay dilakukan dengan menggunakan software ArcGis 10.3, melalui tiga langkah. Pertama adalah konversi data vektor ke raster. Data vektor berisikan atribut pada setiap sub kriteria yang terbentuk per ruas jalan. Langkah kedua adalah Reclassify. Tahap ini bertujuan mengklasifikasikan nilai subjek atau skoring tingkat kepentingan masing-masing atribut pada setiap sub kriteria per ruas jalan. Penentuan jumlah kelas sebagai analisis penilaian evaluasi tingkat kepentingan, didasarkan pada indikator pada masing-masing variabel. Untuk variabel yang tidak memiliki indikator tertentu, penentuan jumlah kelas dan interval menggunakan rumus sturges. Langkah terakhir adalah weighted overlay. Input yang digunakan adalah semua raster yang telah di reclassify. Pada jendela toolbox weighted overlay akan diberikan masukan pembobotan yang telah didapatkan pada tahap AHP.

\subsection{Gambaran Umum Wilayah Penelitian}

Kota Kediri merupakan kota Orde IIB, yaitu termasuk dalam klasifikasi Kota Menengah, dengan luas $63,4 \mathrm{~km}^{2}$. Kota Kediri memiliki fungsi sebagai salah satu pusat pelayanan di tingkat propinsi. Ini disebutkan dalam RTRW Propinsi Jawa Timur 2011 - 2030 (2012), bahwa Kota Kediri merupakan pusat pengembangan SWP (Satuan Wilayah Pengembangan) untuk Kediri dan sekitarnya yang meliputi Kabupaten Kediri, Nganjuk, Trenggalek dan Tulungagung. Sebagai pusat pengembangan SWP, Kota Kediri memiliki fungsi sebagai pusat pelayanan tersier yakni industri, perdagangan, pemerintahan dan pendidikan tinggi. Keberadaan economic base, yakni industri pengolahan tembakau (PT. Gudang Garam), memberikan andil yang cukup besar sebagai pendorong utama aktivitas perekonomian masyarakat. Sesuai dengan hal tersebut, maka arahan penyebaran kegiatan-kegiatan pembangunan dialokasikan pada bagian wilayah kota secara merata sesuai dengan kecenderungan perkembangannya. Fungsi Kota Kediri sebagai pusat pelayanan bagi wilayah sekitarnya, tumbuh dan berkembang didukung oleh keberadaan infrastruktur transportasi yang menghubungkan dengan beberapa daerah disekitarnya. Keberadaan infrastruktur 
Christiawan, Basuki / Jurnal Pembangunan Wilayah dan Kota, Vol 15, No1, 2019, 33-46 Doi: 10.14710/pwk.v15i1.21066

transportasi mempengaruhi pola pemanfaatan lahan yang cenderung linier terutama di sepanjang jalan arteri primer arah ke Surabaya. Kota Kediri berada pada jalur transportasi regional yang menghubungkan Kota Surabaya dengan Tulungagung, Nganjuk dan Malang, dalam konteks pengembangan wilayah Provinsi Jawa Timur. Adapun peta propinsi Jawa Timur terlihat dalam Gambar 2.

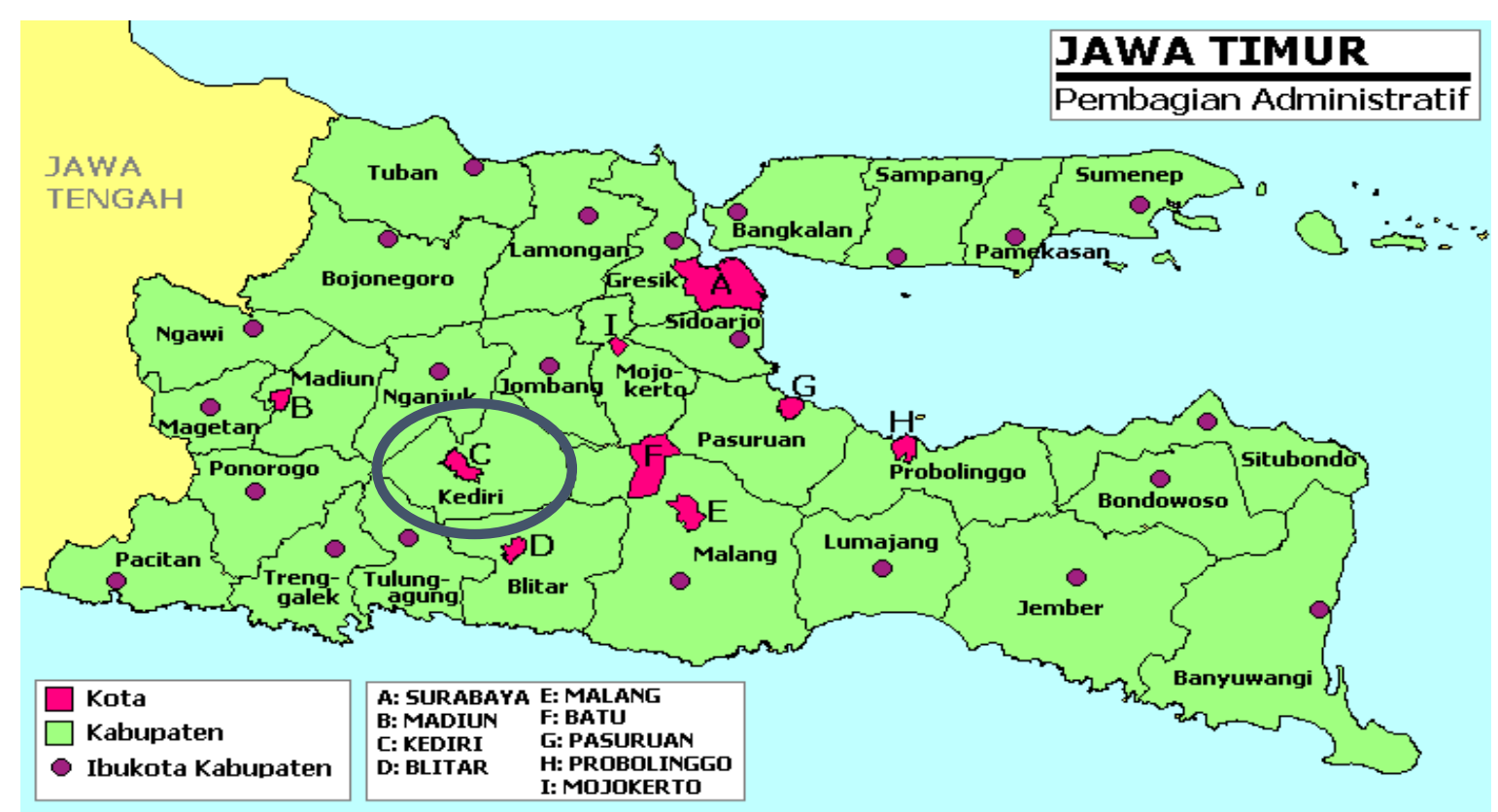

Gambar 2. Peta Propinsi Jawa Timur (RTRW Propinsi Jawa Timur 2011 -2031, 2012)

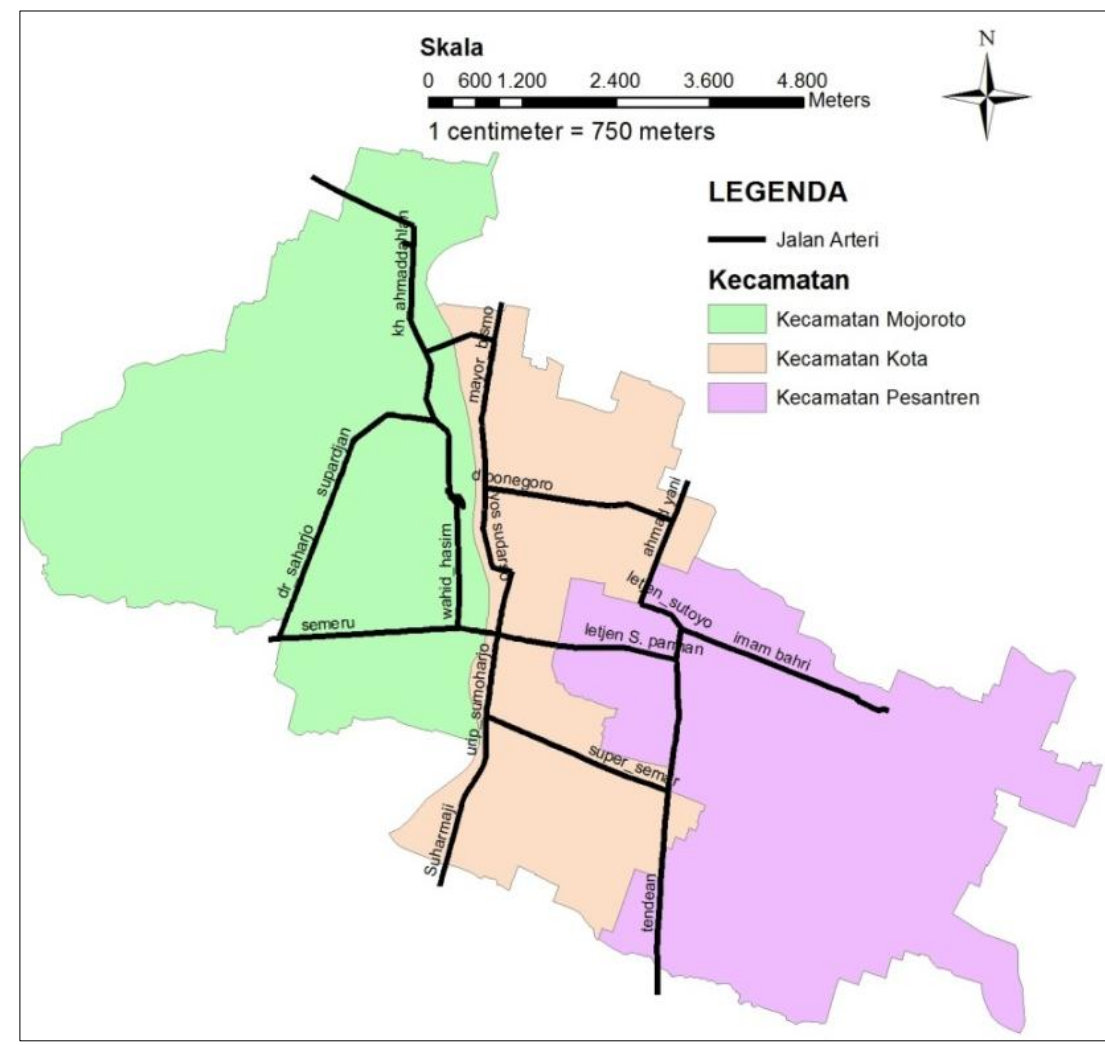

Gambar 3. Jalan Arteri Kota Kediri (Penulis, 2018) 
Peranan kota kediri sebagai salah satu pusat pelayanan di Jawa timur dibuktikan juga dengan rencana penambahan ruas jalan tol Kediri-Nganjuk sepanjang $22 \mathrm{~km}$, yang disebabkan peningkatan volume lalu lintas akibat meningkatnya aktivitas kota (Yudono Yanuar, 2018, https://bisnis.tempo.co/read/1048404/diluar-solo-ngawi-kertosono-jasa-marga-tambah-175-km-tol-baru, 25 Mei 2018). Selain jalan tol, rencana pengembangan Kota Kediri juga akan dipengaruhi dengan adanya rencana pembangunan bandara. PT. Gudang Garam berencana untuk membangun bandara yang terletak di Desa Bulusari di Kecamatan Tarokan, Desa Grogol kec Grogol, serta desa jatirejo dan desa tiron kecamatan banyakan (Jawa Pos, 2018, https://www.pressreader.com/indonesia/jawa-pos/20180215/282140701 845737, 25 Mei 2018). Pada sektor ruas jalan, Kota Kediri dilewati oleh 35 ruas jalan arteri yang berfungsi sebagai jalur transportasi utama dalam skala regional. Ruas jalan arteri tersebut juga berfungsi dalam meningkatkan peran Kota Kediri dalam melayani daerah di sekitarnya. Penelitian ini berfokus pada 35 ruas jalan arteri tersebut. Adapun gambaran mengenai ruas jalan arteri kota Kediri dapat dilihat dalam Gambar 3.

Penentuan ruas jalan tersebut didasarkan pada tingkat prioritas fungsi jalan, efisiensi daya dan biaya, kerawanan kecelakaan, serta permasalahan teknis penerangan jalan. Berdasarkan fungsi, jalan arteri memiliki prioritas yang lebih tinggi daripada jalan kolektor, jalan lokal, serta jalan lingkungan. Penggunaan jenis lampu dengan daya tinggi sebagian besar digunakan untuk jalan arteri. Penggunaan jenis lampu tersebut memang diperlukan untuk memenuhi standar penerangan jalan, namun hal tersebut jauh dari efisiensi dan menyebabkan emisi CO2 yang tinggi. Berdasarkan data dari Kepolisian Resort Kota Kediri tahun 2017, diketahui bahwa jumlah kejadian kecelakaan tertinggi terjadi di jalan arteri. Hal lain adalah banyaknya permasalahan teknis di bidang penerangan jalan yang terjadi di jalan arteri.

Berdasarkan observasi lapangan diketahui bahwa layanan penerangan jalan di jalan arteri Kota Kediri belum memenuhi standar minimal spesifikasi penerangan jalan di perkotaan (SNI $7391: 2008$ ). Untuk ratio kemerataan, standar yang ditetapkan untuk kawasan komersil adalah minimal 3:1, sedangkan untuk kawasan perumahan dan lainnya minimal 6:1. Pada data yang di dapat, semua ruas jalan arteri tidak memenuhi standar kemerataan. Ratio kemerataan yang paling mendekati standar minimal adalah di Jalan Iskandar Muda dan Jalan Letjen Suprapto, yang mencapai 8:1. Ratio kemerataan yang paling buruk pada Jalan Suparjan Mangun Wijaya yang mencapai 39:1. Faktor-faktor yang mendukung ratio kemerataan adalah jarak antar tiang LPJU dan ketinggian lampu. Jarak antar tiang LPJU pada jalan arteri di Kota Kediri bervariasi antara 20 - 60 meter. Jika dibandingkan dengan standar (min 28 meter), maka hanya ada 1 ruas jalan yang memenuhi standar, yaitu jalan Iskandar Muda.

Faktor lain yang mempengaruhi kemerataan pencahayaan adalah ketinggian lampu. Berdasarkan SNI 7391 : 2008, syarat paling rendah ketinggian lampu untuk lebar jalan 11 meter dan lebih adalah minimal 10 meter. Berdasarkan standar, tidak ada satupun ruas jalan arteri di Kota Kediri yang memenuhi standar ketinggian lampu. Pada data diketahui bahwa ketinggian lampu jalan di Kota Kediri bervariasi antar 5,5- 8 meter. Hal ini disebabkan karena terbatasnya sarana operasional perawatan berupa mobil hidrolis yang hanya mencapai ketinggian 8 meter. Faktor lain yang menjadi permasalahan layanan penerangan jalan di Kota Kediri adalah pada KWH Meter. Melalui pengamatan di lapangan diketahui hanya ada 2 ruas jalan yang menggunakan KWH meter dengan $M C B$ yang sesuai. Hal tersebut berpengaruh pada efisiensi biaya dan tingkat kerusakan yang terjadi. Begitu pula dengan penggunaan jenis lampu, sebagian besar menggunakan lampu SON 250 watt yang termasuk lampu bertegangan tinggi. Penggunaan lampu tersebut memiliki pengaruh yang kuat pada tingkat efisiensi biaya dan pencemaran Co2. Data lain terkait gambaran ruas jalan arteri di Kota kediri seperti Gambar 4 sampai dengan Gambar 7. 
Christiawan, Basuki / Jurnal Pembangunan Wilayah dan Kota, Vol 15, No1, 2019, 33-46 Doi: 10.14710/pwk.v15i1.21066

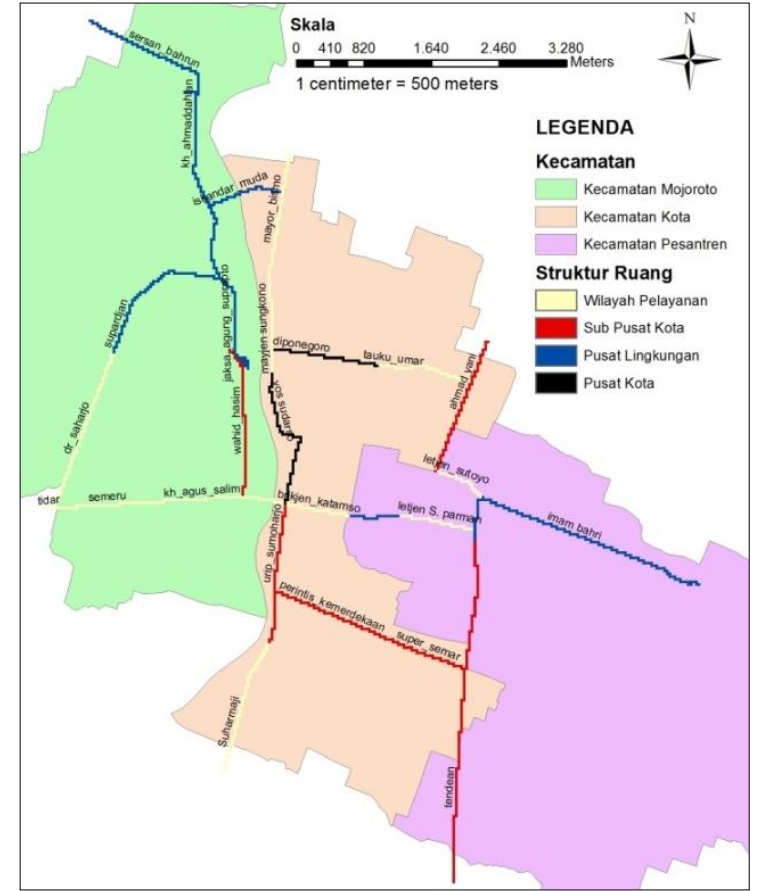

Gambar 4. Struktur Ruang Setiap Ruas Jalan (Analisis 2018)

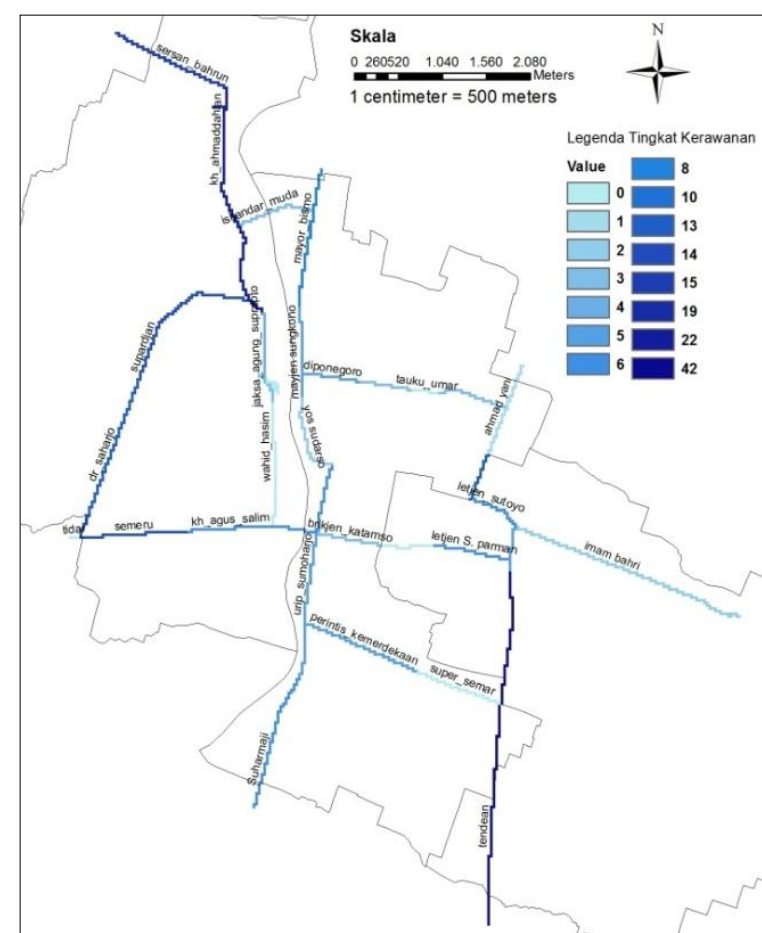

Gambar 6. Tingkat Kerawanan Ruas Jalan (Analisis 2018)

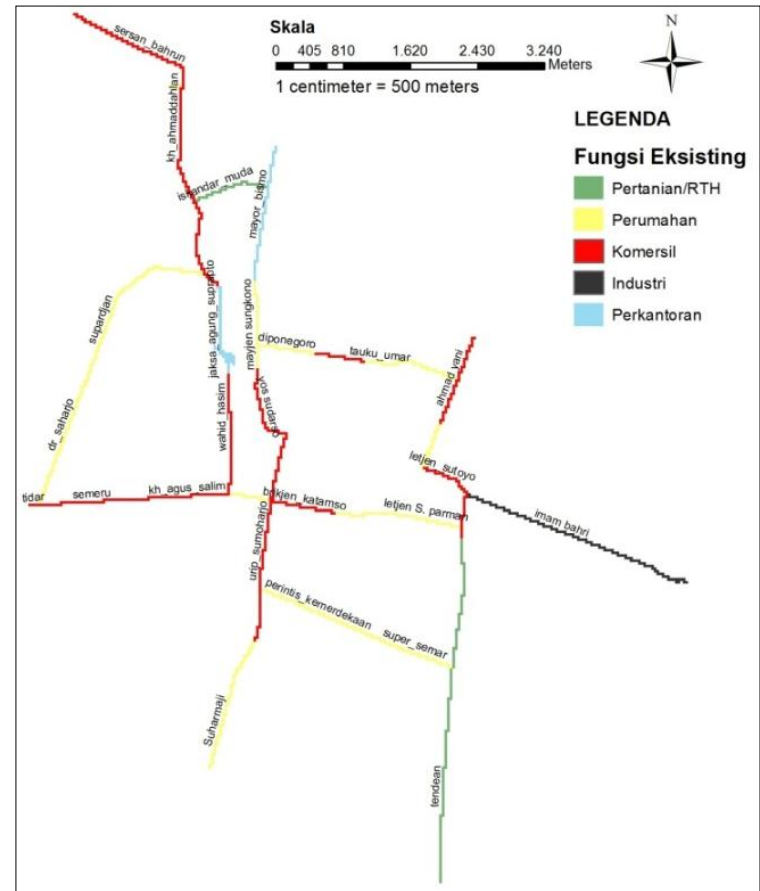

Gambar 5. Fungsi Eksisting Setiap Ruas Jalan (Analisis 2018)

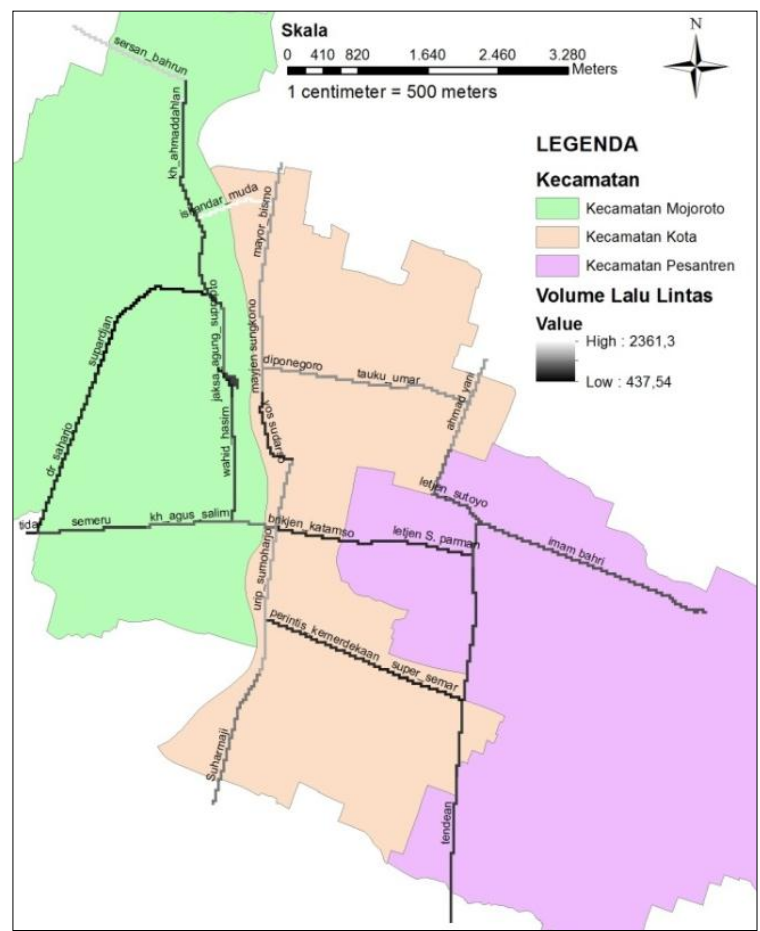

Gambar 7. Volume Lalu Lintas Ruas Jalan (Analisis 2018)

Gambar 4 menunjukkan struktur ruang pada setiap jalan arteri. Struktur ruang dengan hirarki paling tinggi adalah pusat kota, diikuti dengan sub pusat kota, pusat lingkungan, dan hirarki yang paling rendah adalah wilayah pelayanan. Gambar 5 menunjukkan fungsi lahan pada ruas jalan arteri. Fungsi lahan menentukan tingkatan hirarki pada tiap ruas jalan. SNI 7391:2008 menjelaskan bahwa penerangan jalan 
pada kawasan komersil, memiliki standar tingkat kemerataan yang lebih tinggi yaitu 3:1, sedangkan pada perumahan 6:1, dan semakin kecil pada fungsi yang lain. Pada kawasan komersil, kepentingan penerangan jalan juga perlu lebih diperhatikan atau diutamakan karena memiliki fungsi tambahan untuk meningkatkan omset penjualan (Jin et al, 2017). Pada kawasan industri, ruas jalan berfungsi tidak hanya untuk lalu lintas secara umum, namun juga untuk distribusi barang. Urutan berikutnya adalah kawasan perumahan, karena hanya digunakan untuk lalu lintas orang. Kawasan perumahan tidak memiliki fungsi tambahan untuk distribusi barang pada malam hari maupun menambah omset penjualan seperti pada kawasan komersil dan industri. Fungsi Perkantoran dan Sawah/RTH memiliki tingkat kepentingan pada urutan yang relatif rendah. Ini dikarenakan pada fungsi perkantoran dan sawah, aktivitas lebih banyak dilakukan pada siang hari. Fungsi perkantoran memiliki nilai kepentingan yang sedikit lebih tinggi, karena pada kawasan perkotaan fungsi perkantoran memiliki NJOP yang lebih tinggi daripada fungsi persawahan.

Gambar 6 menunjukkan tingkat kerawanan setiap ruas jalan. Warna biru muda menunjukkan tingkat kerawanan yang rendah, dan semakin berwarna tua pada tingkat kerawanan yang tinggi. Tingkat kerawanan yang paling tinggi terlihat pada jalan Kapten Tendean. Gambar 7 menunjukkan volume lalu lintas setiap ruas jalan. Semakin gelap warna yang ditunjukkan berarti semakin tinggi volume lalu lintas pada ruas jalan tersebut. Volume lalu lintas tertinggi berada pada jalan Gatot Subroto yaitu 1895,35 smp/jam.

\section{HASIL DAN PEMBAHASAN}

3.1. Pembobotan Kriteria dan Sub Kriteria Penentuan Prioritas Peningkatan Pelayanan Penerangan Jalan

Penentuan bobot kriteria dan sub kriteria dilakukan dengan membandingkan tingkat kepentingan antar kriteria dan antar sub kriteria berdasarkan hasil pengisian kuisioner oleh expert. Langkah awal dari pembobotan adalah menilai tingkat konsistensi jawaban expert. Konsistensi rasio harus kurang dari atau sama dengan $10 \%$. Jika lebih dari $10 \%$ maka perlu dilakukan pengulangan pengisian kuisioner. Hasil dari kuisioner perbandingan kepentingan kriteria dapat dilihat pada tabel 2.

Tabel 2. Perbandingan Kepentingan Antar Kriteria (Analisis, 2018)

\begin{tabular}{|c|c|c|c|c|c|c|c|c|c|c|c|}
\hline \multirow{2}{*}{ Responden } & \multicolumn{10}{|c|}{ Perbandingan Tingkat Kepentingan Antar Kriteria } & \multirow{2}{*}{ CR } \\
\hline & GJ : TL & GJ:KLL & GJ:EDB & GJ:PW & TL:KLL & TL:EDB & TL:PW & KLL:EDB & KLL:PW & EDB:PW & \\
\hline Dinas PUPR & 3,000 & 3,000 & 5,000 & 0,333 & 3,000 & 5,000 & 0,333 & 3,000 & 0,333 & 0,200 & $10 \%$ \\
\hline Barenlitbang & 2,000 & 3,000 & 2,000 & 3,000 & 2,000 & 5,000 & 2,000 & 4,000 & 2,000 & 1,000 & $8 \%$ \\
\hline UNIK & 1,000 & 1,000 & 1,000 & 3,000 & 0,333 & 3,000 & 0,333 & 3,000 & 1,000 & 0,333 & $2 \%$ \\
\hline Dishub & 3,000 & 1,000 & 3,000 & 1,000 & 1,000 & 3,000 & 3,000 & 3,000 & 1,000 & 1,000 & $6 \%$ \\
\hline DPKP & 0,200 & 0,200 & 3,000 & 3,000 & 3,000 & 7,000 & 5,000 & 1,000 & 5,000 & 0,500 & $10 \%$ \\
\hline Polres & 3,000 & 0,200 & 1,000 & 0,333 & 1,000 & 3,000 & 0,333 & 3,000 & 1,000 & 3,000 & $5 \%$ \\
\hline
\end{tabular}

\begin{tabular}{lll}
\multicolumn{2}{l}{ Keterangan } \\
GJ & $:$ Gambaran Jalan \\
TL & $:$ Teknis Lampu Penerangan Jalan Umum \\
KLL & $:$ Kondisi lalu Lintas \\
EDB & $:$ Efisiensi Daya dan Biaya \\
PW & $:$ Pengembangan Wilayah \\
CR & $:$ Consistency Ratio
\end{tabular}

Langkah selanjutnya adalah mengkonversi gabungan perbandingan kepentingan kriteria oleh 6 orang responden dan kemudian melakukan normalisasi matrik dan pengulangan iterasi sampai dengan selisih antar iterasi tidak mengalami perubahan atau sama dengan nol. Berdasarkan langkah tersebut, maka didapatkan bobot kriteria dan sub kriteria seperti pada tabel 3 . 
Christiawan, Basuki / Jurnal Pembangunan Wilayah dan Kota, Vol 15, No1, 2019, 33-46

Doi: 10.14710/pwk.v15i1.21066

Tabel 3. Hasil Akhir Pembobotan Kriteria dan Sub Kriteria (Analisis, 2018)

\begin{tabular}{|c|c|c|c|}
\hline \multirow{2}{*}{ No. } & \multicolumn{3}{|c|}{ Kriteria Gambaran Jalan (22,3\%) } \\
\hline & Sub Kriteria & bobot & Bobot Total \\
\hline 1 & Lebar jalan & $27,9 \%$ & $6,22 \%$ \\
\hline 2 & Jumlah Persimpangan & $56 \%$ & $12,49 \%$ \\
\hline \multirow[t]{3}{*}{3} & Jumlah Jembatan & $16,2 \%$ & $3,61 \%$ \\
\hline & \multicolumn{3}{|c|}{ Kriteria Teknis LPJU $(26,6 \%)$} \\
\hline & Sub Kriteria & bobot & Bobot Total \\
\hline 4 & Jarak Antar Tiang & $44,6 \%$ & $11,86 \%$ \\
\hline 5 & Ketinggian Lampu & $14,6 \%$ & $3,88 \%$ \\
\hline 6 & Tingkat Pencahayaan & $23,7 \%$ & $6,30 \%$ \\
\hline \multirow[t]{3}{*}{7} & Tingkat Kegagalan Penerangan Jalan & $17,2 \%$ & $4,58 \%$ \\
\hline & \multicolumn{3}{|c|}{ Kriteria Kondisi Lalu Lintas (22,5\%) } \\
\hline & Sub Kriteria & bobot & Bobot Total \\
\hline 8 & Tingkat Kerawanan Kecelakaan & $71,1 \%$ & $16,00 \%$ \\
\hline \multirow[t]{3}{*}{9} & Volume Lalu Lintas & $28,8 \%$ & $6,48 \%$ \\
\hline & \multicolumn{3}{|c|}{ Kriteria Efisiensi Daya dan Biaya (8,6 \%) } \\
\hline & Sub Kriteria & bobot & Bobot Total \\
\hline 10 & Penggunaan Jenis Lampu & $49,7 \%$ & $4,27 \%$ \\
\hline 11 & Penggunaan KWH Meter & $27,6 \%$ & $2,37 \%$ \\
\hline \multirow[t]{3}{*}{12} & Penggunaan Daya & $22,7 \%$ & $1,95 \%$ \\
\hline & \multicolumn{3}{|c|}{ Kriteria Pengembangan Wilayah (20,1\%) } \\
\hline & Sub Kriteria & bobot & Bobot Total \\
\hline 13 & Fungsi Eksisting Koridor & $43,8 \%$ & $8,80 \%$ \\
\hline 14 & Fungsi Rencana Koridor & $26,3 \%$ & $5,29 \%$ \\
\hline 15 & Struktur Ruang & $29,9 \%$ & $6,01 \%$ \\
\hline
\end{tabular}

Berdasarkan perhitungan bobot kriteria dan sub kriteria, maka dihasilkan nilai akhir bobot masingmasing variabel yang digunakan dalam menentukan prioritas peningkatan layanan penerangan jalan arteri di Kota Kediri. Pengaruh tertinggi adalah variabel tingkat kerawanan dengan nilai sebesar $16 \%$, yang diikuti dengan jumlah persimpangan 12,49\% dan jarak antar tiang 11,86\%. Sedangkan pengaruh terendah adalah variabel penggunaan daya sebesar 1,95\%. Sesuai dengan fungsi utamanya, penerangan jalan berguna untuk meningkatkan keselamatan pengguna jalan, sehingga diatur dalam SNI 7391:2008 bahwa kerawanan lokasi merupakan variabel yang perlu dipertimbangkan. Selaras dengan peraturan tersebut, stakeholder di Kota Kediri juga memberikan bobot utama peningkatan layanan penerangan jalan yang ditujukan untuk meningkatkan keselamatan pengguna jalan pada ruas jalan dengan tingkat kerawanan tinggi. Menurut Saraiji et al (2009), salah satu penyebab kerawanan lokasi adalah kurangnya penerangan jalan. Dibuktikan dalam penelitiannya, bahwa $85 \%$ kecelakaan terjadi pada ruas jalan yang memiliki penerangan jalan tidak sesuai dengan standar.

Kurangnya penerangan jalan tidak dapat dikatakan sebagai satu satunya penyebab kecelakaan, karena banyak faktor lain yang menyebabkan terjadinya kecelakaan. Namun dari penelitian tersebut, jelas dikatakan kerawanan lokasi merupakan point penting yang harus diperhatikan dalam meningkatkan penerangan jalan. Kristiyono et al (2010) , juga menggunakan tingkat kerawanan lokasi dan jumlah kecelakaan setiap ruas jalan dalam menentukan penataan lampu penerangan jalan umum di Kabupaten Ponorogo. Pada penelitiannya dijelaskan bahwa sejumlah 43 permohonan ijin pemasangan lampu jalan di tahun 1999-2000, berada pada ruas jalan yang memiliki kerawanan yang tinggi. Jumlah persimpangan merupakan variabel tertinggi kedua yang harus diperhatikan menurut stakeholder di Kota Kediri. Dalam SNI 7391:2008 persimpangan jalan merupakan elemen penting yang harus diperhatikan. Terhitung dua kali 
disebutkan bahwa dalam merencanakan penerangan jalan perlu mempertimbangkan adanya persimpangan.

Pertama adalah perencanaan penerangan jalan harus memperhatikan tipikal persimpangan jalan, situasi tata letak jalan dan persimpangan. Kedua adalah perencanaan penerangan jalan harus memperhatikan tempat-tempat yang memerlukan perhatian khusus, salah satunya adalah tempat yang luas seperti persimpangan interchange, tempat parkir, dll; jalan-jalan berpohon. Berdasarkan peraturan tersebut jelas disimpulkan bahwa semakin banyak persimpangan pada ruas jalan, maka perencanaan penerangan jalannya harus lebih diprioritaskan. Penelitian Saraiji et al (2009) menjelaskan bahwa sebagian besar kecelakaan di ruas jalan terjadi di sekitar persimpangan. Kecelakaan sering terjadi pada radius 250 kaki atau sekitar 76,2 meter dari persimpangan, dan menurun jumlahnya diluar radius tersebut. Pada perempatan dengan penerangan jalan kurang dari 4 tiang, memiliki tingkat kecelakaan yang lebih tinggi daripada perempatan dengan 4 tiang penerangan jalan. Kristiyono et al (2010) menambahkan bahwa permohonan ijin penerangan jalan di Kabupaten Ponorogo sebagian besar adalah pada persimpangan jalan.

Penerangan jalan pada persimpangan juga memiliki standar yang berbeda dibandingkan dengan jalan yang lurus. Pada SNI 7391:2008 disebutkan bahwa pencahayaan yang lebih tinggi diutamakan pada tikungan atau persimpangan, daripada bagian jalan yang lurus. Penempatan penerangan jalan di persimpangan dilakukan dengan menggunakan lampu menara dengan beberapa lampu. Variabel yang paling berpengaruh lainnya adalah jarak antar tiang LPJU. Variabel ini sangat berhubungan dengan pemerataan sinar lampu. Banyak ditemukan permasalahan penerangan jalan yang tidak sesuai standar, dikarenakan jarak antar tiang lampu yang terlalu jauh. Murray dan Feng (2016), menemukan bahwa penempatan tiang Lampu PJU yang kurang dari standar akan mengurangi fungsi dari LPJU.

Garrido-Jiménez et al (2017) menyebutkan bahwa tujuan pembangunan berkelanjutan sangat bergantung pada design dan infrastruktur perkotaannya. Pada penerangan jalan, design yang dimaksud adalah jarak dan ketinggian lampu jalan. Jarak dan ketinggian lampu perlu diperhatikan untuk mendapatkan layanan penerangan lampu jalan yang optimal. Jika dibandingkan dengan kriteria teknis yang lain, jarak tiang merupakan variabel yang paling berpengaruh terhadap kriteria teknis penerangan jalan, yaitu sebesar 44,6\%. Tidak hanya di Indonesia, di USA juga diatur teknis jarak antar tiang penerangan jalan. Ini membuktikan bahwa variabel tersebut merupakan faktor yang penting. Penentuan jarak antar lampu di USA, menggunakan pertimbangan kualitas lampu penerangan, spesifikasi lampu yang dikeluarkan oleh pabrik, lebar jalan, serta ketinggian bangunan sekitar. Pada SNI 7391:2008 juga telah ditentukan standar minimal jarak antar tiang penerangan jalan berdasarkan lebar jalan, kuat lampu penerangan, jenis rumah lampu, serta klasifikasi jalan. Ini artinya bahwa jarak antar tiang merupakan suatu variabel perencanaan teknis yang sangat penting.

\subsection{Analisis Penentuan Prioritas Peningkatan Layanan Penerangan Jalan}

Analisis Penentuan Prioritas Peningkatan Layanan Penerangan Jalan menggunakan dua masukan, yaitu hasil pembobotan AHP dan nilai masing-masing variabel pada setiap ruas jalan. Pada gambar 4 . Jendela Weighted Overlay, masing-masing variabel memiliki tingkat pengaruh dalam penentuan prioritas peningkatan layanan penerangan jalan. Besaran pengaruh tersebut akan dipadukan dengan nilai hasil klasifikasi sesuai dengan nilai masing-masing variabel per ruas jalan. Metode weighted overlay adalah analisis spasial menggunakan beberapa teknik overlay peta terkait dengan faktor-faktor yang mempengaruhi penilaian kerentanan. Salah satu fungsi dari overlay tertimbang ini adalah untuk memecahkan masalah multikriteria seperti pemilihan lokasi yang optimal atau pemodelan konformitas. Weighted Overlay adalah salah satu fasilitas yang ada di ArcGIS yang menggabungkan berbagai input dalam bentuk peta grid berbobot (weighted factor) dari ahli. Penggunaan metode ini menggunakan data raster yang memiliki satuan piksel terkecil sehingga dapat diberi skor dan pembobotan setiap piksel yang memiliki nilai masing-masing. Overlay beberapa raster menggunakan skala pengukuran umum dan berat masing-masing sesuai dengan kepentingannya. 


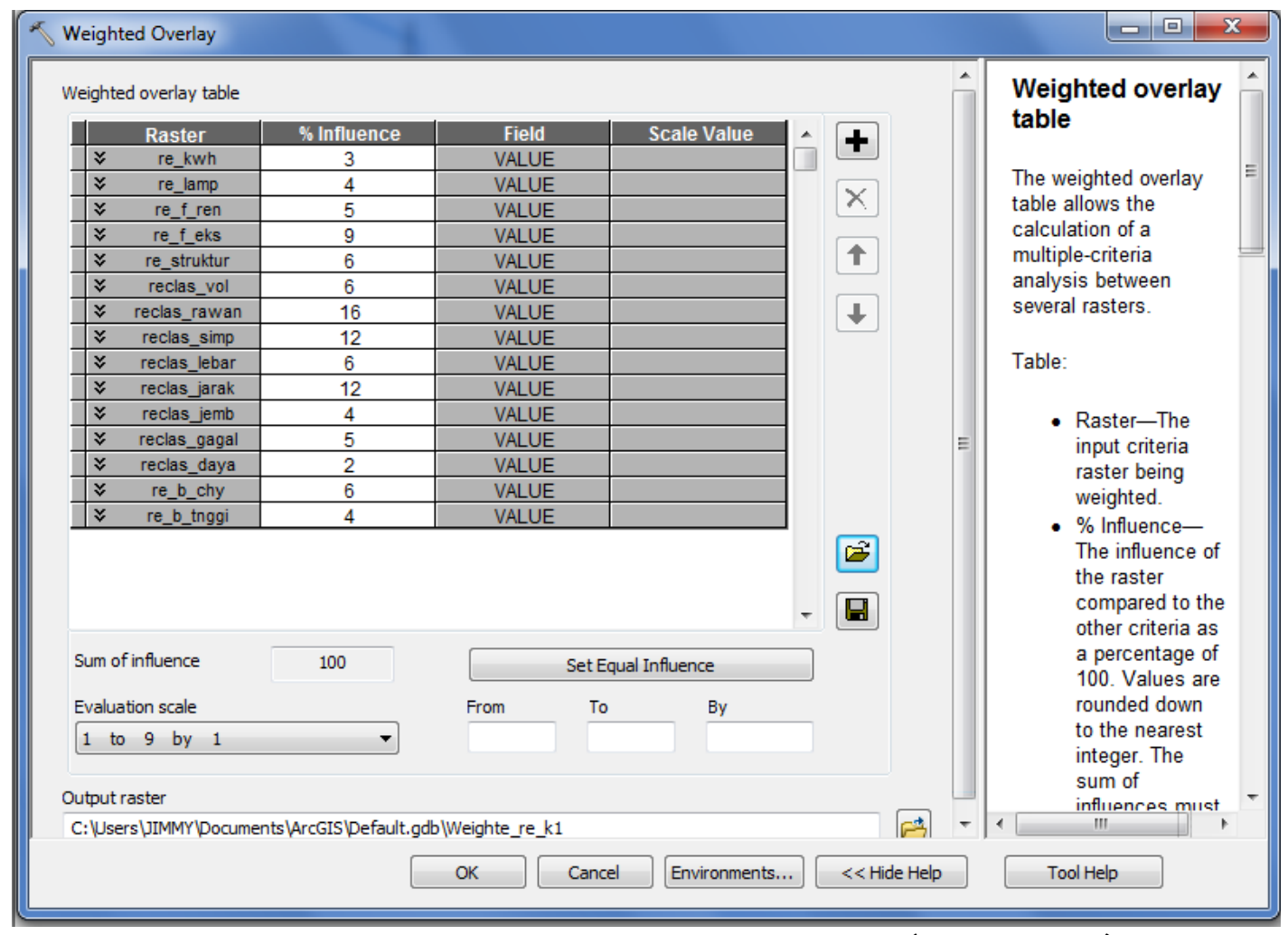

Gambar 4. Jendela Analisis Weighted Overlay (Penulis, 2018)

Semua input raster pada penggunaan weighted overlay harus berupa bilangan bulat. Raster floatingpoint pertama-tama harus dikonversi ke raster integer sebelum dapat digunakan dalam overlay tertimbang. Setiap kelas nilai dalam raster masukan diberi nilai baru berdasarkan skala evaluasi. Setiap raster yang dimasukkan diberi bobot sesuai dengan kepentingannya atau diwakili oleh persentasenya, jumlah persen efek berat harus 100. Perubahan pada skala evaluasi atau pengaruh persentase dapat mengubah hasil analisis weighted overlay (Adininggar et al, 2015). Analisis weighted overlay menghasilkan data raster yang memiliki nilai berupa penjumlahan skor masing-masing variabel sesuai dengan bobot dan klasifikasinya. Hasil analisis seperti pada gambar 5. 


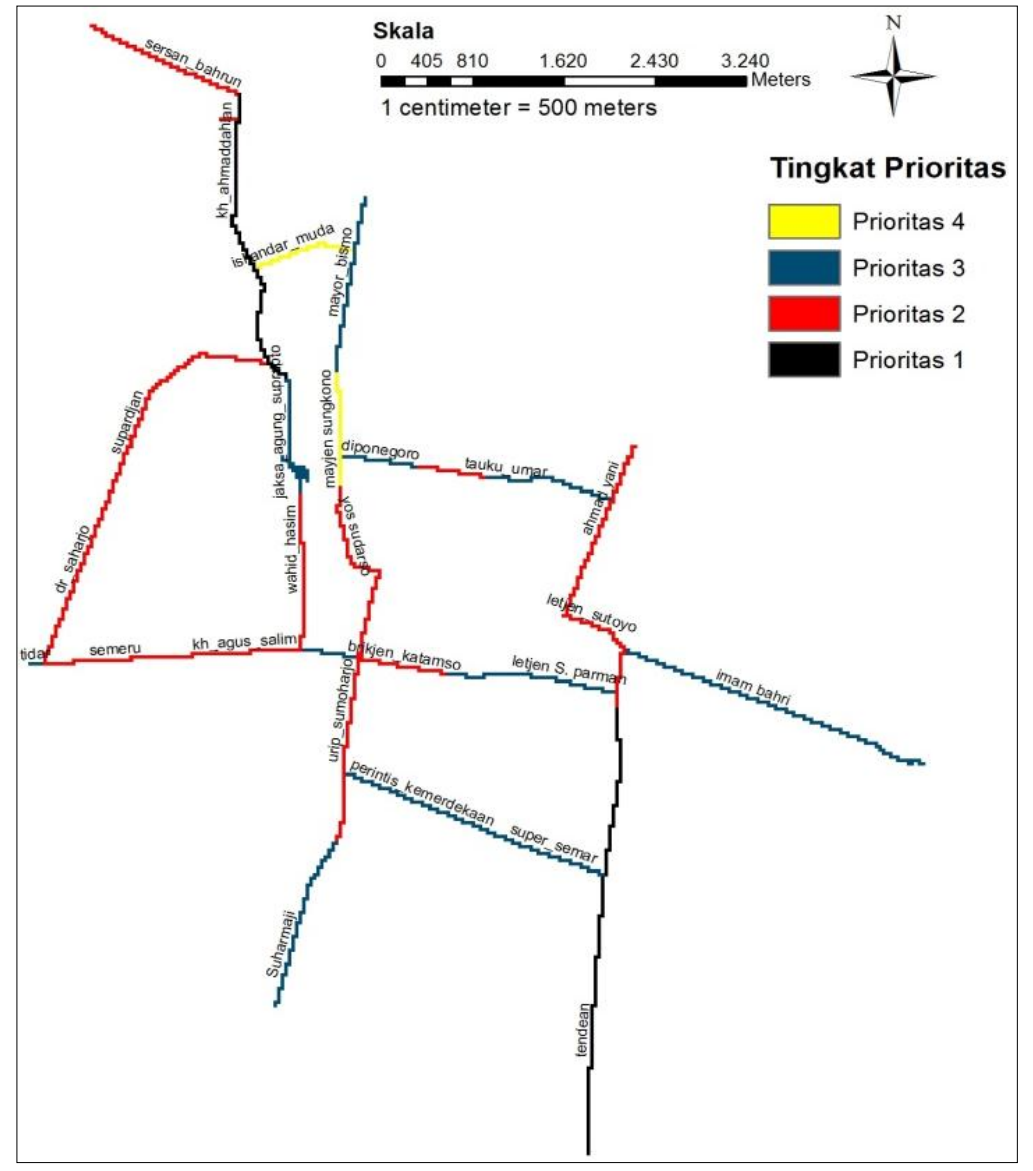

Gambar5. Hasil Analisis Wighted Overlay (Analisis, 2018)

Berdasarkan hasil dari analisis, terdapat 4 tingkatan prioritas dalam peningkatan pelayanan penerangan jalan di Kota Kediri. Tingkatan prioritas ini dihasilkan dari perpaduan antara reklasifikasi nilai setiap ruas jalan berdasarkan variabel dan persentase kepentingan variabel berdasarkan AHP. Prioritas pertama terdiri dari 2 ruas jalan, prioritas kedua terdiri dari 16 ruas jalan, prioritas ketiga terdiri dari 15 ruas jalan, dan prioritas keempat terdiri dari 2 ruas jalan.

\subsection{Hasil Penentuan Prioritas Peningkatan Layanan Penerangan Jalan}

Prioritas pertama terdiri dari Ruas Jalan Kapten Tendean dan K.H Ahmad Dahlan. Ditinjau dari observasi lapangan, kedua ruas jalan tersebut memang memiliki nilai yang tinggi pada hampir semua variabel. Pada variabel tingkat kerawanan dan jumlah persimpangan yang merupakan variabel dengan bobot tertinggi, jalan Kapten Tendean memiliki nilai yang paling tinggi dibandingkan dengan ruas jalan yang lain. Tingkat kerawanan pada jalan Kapten Tendean adalah 42; K.H. Ahmad Dahlan 22; sedangkan ruas jalan yang lain memiliki tingkat kerawanan rata-rata 8. Jumlah persimpangan jalan Kapten Tendean adalah 25, menduduki peringkat pertama, sedangkan jalan K.H. Ahmad Dahlan sejumlah 15 menduduki peringkat ke empat. Pada aspek teknis, kedua ruas jalan tersebut belum memenuhi standar pelayanan minimal sesuai dengan SNI 7391:2008. Jarak antar LPJU pada jalan Kapten Tendean adalah 45 meter dengan ketinggian lampu rata-rata adalah 6,5 meter. Menurut standar jarak antar lampu jalan adalah 28 meter untuk lebar jalan 11 meter atau lebih, sedangkan untuk tinggi LPJU, dengan lebar jalan 11 meter atau lebih ketinggian lampu yang disyaratkan adalah 10 meter atau lebih.

Ditinjau dari kemerataan pencahayaan, kedua ruas jalan tidak memenuhi persyaratan. Pada SNI 7391:2008 dijelaskan bahwa penerangan jalan pada kawasan komersil, memiliki standar tingkat kemerataan yang lebih tinggi yaitu 3:1, sedangkan pada perumahan 6:1. Jalan Kapten Tendean memiliki 
fungsi campuran sebagai kawasan komersil dan perumahan saat ini, sehingga standar kemerataan cahaya minimal adalah 6:1, sedangkan jalan K.H. Ahmad Dahlan memiliki fungsi sebagai kawasan komersil. Tingkat pencahayaan pada Kapten Tendean adalah 35 lux pada titik pusat jatuhnya cahaya, dan 2 lux pada titik terjauh jatuhnya cahaya. Kondisi tersebut memiliki perbandingan kemerataan 17,5:1, sangat jauh dari standar yang ditetapkan. Begitu juga dengan jalan K.H. Ahmad Dahlan yang memiliki perbandingan kemerataan 19,5:1. Selain berdasarkan ketiga variabel dengan bobot tertinggi, ruas jalan tersebut menggunakan lampu SON 250 watt, yang menggunakan daya tinggi dan menghasilkan emisi Co2 yang tinggi, dan menggunakan KWH meter dengan MCB yang tidak sesuai dengan kontrak PLN.

Prioritas paling akhir, yaitu prioritas ke empat adalah ruas jalan Iskandar Muda dan Mayjen Sungkono. Tingkat kerawanan pada kedua ruas jalan ini relatif rendah, yaitu 3 pada jalan iskandar muda, dan 5 pada jalan mayjen sungkono. Pada variabel jumlah persimpangan, jalan iskandar muda tidak memiliki jumlah persimpangan, sedangkan jalan mayjen sungkono hanya 6 persimpangan. Semakin sedikit jumlah persimpangan suatu ruas jalan, maka resiko kecelakaan juga semakin rendah. Pada aspek teknis, kedua ruas jalan ini hampir mendekati standar yang disyaratkan. Jarak antar lampu jalan pada jalan iskandar muda telah memenuhi persyaratan, yaitu 20 meter dengan ketinggian 8 meter. Meskipun ketinggian lampu belum sesuai, namun kemerataan cahaya pada jalan iskandar muda telah memenuhi persyaratan karena jarak antar lampu sudah lebih dari yang dipersyaratkan yaitu 28 meter. Begitu pula dengan jalan mayjen sungkono yang memiliki jarak antar lampu 30 meter dengan ketinggian 7 meter, sudah mendekati standar. Hal positif lain adalah pada ruas jalan mayjen sungkono telah menggunakan lampu LED, yang lebih efisien dibandingkan lampu SON 250 watt.

\section{KESIMPULAN}

Stakeholder memiliki peran yang penting dalam perencanaan penerangan jalan. Tidak hanya Dinas Perumahan dan Kawasan Pemukiman, selaku unit kerja yang membidangi penerangan jalan, namun peran stakeholder yang lain juga diperlukan. Ini karena perencanaan penerangan jalan tidak hanya dari kriteria teknis, namun juga mempertimbangkan kriteria yang lain seperti gambaran jalan, kondisi lalu lintas, efisiensi daya dan biaya, serta pengembangan wilayah. Bobot tertinggi dalam perencanaan peningkatan penerangan jalan adalah tingkat kerawanan kecelakaan (16\%), yang termasuk dalam kriteria kondisi lalu lintas. Pengaruh tertinggi berikutnya adalah jumlah persimpangan (12,49\%), yang termasuk dalam kriteria gambaran jalan. Pengaruh tertinggi ketiga adalah jarak antar tiang $(11,86 \%)$, yang termasuk pada kriteria teknis LPJU.

Pembobotan variabel-variabel terbentuk sangat diperlukan dalam penentuan prioritas peningkatan layanan peneranangan jalan di Kota Kediri. Tidak hanya dinilai berdasarkan kondisi di lapangan saja, namun bagaimana pengaruh setiap variabel terhadap perencanaan pembangunan penerangan jalan umum. Faktor-faktor seperti terbatasnya dana, terbatasnya daya listrik, usaha meningkatkan keselamatan pengguna jalan, serta usaha dalam mewadahi perkembangan kota; menjadikan penentuan prioritas peningkatan layanan penerangan jalan dapat dilakukan dengan komprehensif dan tepat guna. Berdasarkan hasil analisis, maka Jalan Kapten Tendean dan K.H. Ahmad Dahlan adalah ruas jalan yang harus segera ditingkatkan pelayanan penerangan jalannya. Hasil analisis berupa prioritas pada setiap ruas jalan arteri dapat digunakan sebagai alat bantu bagi pemangku kebijakan dalam menentukan kebijakan peningkatan layanan penerangan jalan di Kota Kediri.

Beberapa variabel yang perlu ditambahkan pada penelitian selanjutnya adalah ketersediaan biaya pembangunan, kedekatan jaringan LPJU untuk peningkatan penggunaan KWH Meter PJU Pintar, serta tingkat kepentingan jalan berdasarakan kegiatan sosial seperti Kediri Night Carnival, Food Festival, Pameran UMKM, dll. Penelitian ini juga dapat digunakan sebagai referensi pada penelitian selanjutnya yang berhubungan dengan penentuan prioritas pembangunan jaringan LPJU baru, penentuan prioritas penanganan perawatan jaringan LPJU, serta sistem informasi jaringan LPJU. 


\section{PERNYATAAN RESMI}

Terima kasih kepada semua pihak yang telah membantu saya dalam menyelesaikan penelitian ini, khususnya Kementerian Pekerjaan Umun dan Perumahan Rakyat Republik Indonesia atas kesempatan dan dukungan pembiayaan yang diberikan selama menjalani masa tugas belajar.

\section{REFERENSI}

Achmad Fauzi. 2018, https://ekonomi.kompas.com/read/2018/03/09/142100226/ gudang garam dipastikan akan bangun bandara di kediri jawa timur. 25 Mei 2018.

Adininggar, F. W., Suprayogi, A., Wijaya, A. P. 2015. Pembuatan Peta Potensi Lahan Berdasarkan Kondisi Fisik Lahan Menggunakan Metode Weigted Overlay, 4(April), 176-184.

al Irsyad, M. I., \& Nepal, R. 2016. A survey based approach to estimating the benefits of energy efficiency improvements in street lighting systems in Indonesia. Renewable and Sustainable Energy Reviews, 58, 1569-1577. https://doi.org/10.1016/j.rser.2015.12.294

Antoro, H. D. 2006. Analisis Hubungan Kecelakaan Dan V/ C Rasio (Studi Kasus : Jalan Tol Jakarta - Cikampek)

Carli, R., Dotoli, M., \& Cianci, E. 2017. An optimization tool for energy efficiency of street lighting systems in smart cities. IFAC-PapersOnLine, 50(1), 14460-14464. https://doi.org/10.1016/j.ifacol.2017.08.2292

Creswell, J. W. 2015. Reserach Design Qualitative, Quantitative, and Mixed Method Approaches.

Feng, X., \& Murray, A. T. 2017. Spatial Analytics for Enhancing Street Light Coverage of Public Spaces. LEUKOS - Journal of Illuminating Engineering Society of North America, o(0), 1-11. https://doi.org/10.1080/15502724.2017.1321486

Garrido-Jiménez, F. J., Magrinyá, F., Moral-Ávila, M. C. del, \& Rodríguez-García, G. 2017. The Relationship Between Urban Morphology and Street Lighting Operating Costs: Evidence from Medium-sized Spanish Cities. Applied Spatial Analysis and Policy, 10(3), 381-399. https://doi.org/10.1007/s12061-0169187-1

Jin, H., Li, X., Kang, J., \& Kong, Z. 2017. An evaluation of the lighting environment in the public space of shopping centres. Building and Environment, 115, 228-235. https://doi.org/10.1016/j.buildenv.2017.01.008

Khaki, A. M., Mojaradi, B., Ghobadipour, B., Maghsoudy, S., \& Naghibi, F. 2015. Integration of GIS and analytical hierarchy process method for locating road emergency medical services station. Geosystem Engineering, 18(2), 92-103. https://doi.org/10.1080/12269328.2015.1006735

Kristiyono, Soemitro, R. A. A., \& Karyadi, A. 2010. Analisa Penentuan Prioritas Penataan Lampu Penerangan Jalan Umum Wilayah Kabupaten Ponorogo.

Mirzaei, M. J., Dashti, R., Kazemi, A., \& Amirioun, M. H. 2015. An asset-management model for use in the evaluation and regulation of public-lighting systems. Utilities Policy, 32, 19-28. https://doi.org/10.1016/j.jup.2014.12.001

Murray, A. T., \& Feng, X. 2016. Public street lighting service standard assessment and achievement. SocioEconomic Planning Sciences, 53, 14-22. https://doi.org/10.1016/j.seps.2015.12.001

RTRW Propinsi Jawa Timur 2011 - 2030 (2012).

Saraiji, R., Sizer, S., Yance-Houser, E., \& Bermejo, F. 2009. Geographic Information System Mapping of Roadway Lighting and Traffic Accidents. Engineering and Technology, 3(6), 517-523. 